\title{
Kadınlarda Serviks Kanserinin Tanısına İlişsin Tutum ve Düzenli Jinekolojik Muayene İlişkisinin Kesitsel Olarak Değerlendirilmesi
}

\author{
Cross-Sectional Evaluation of Reltion Between Women's Attitudes Towards the \\ Diagnosis of Cervical Cancer and Regular Gynecological Examination
}

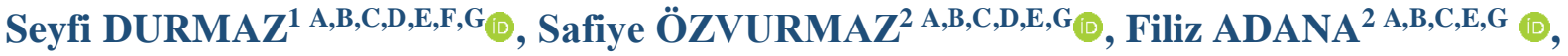 \\ Fatma KURT $^{3}$ B,C,E, $\mathbf{G}_{\text {(B) }}$
}

Ege Üniversitesi Tıp Fakültesi Halk Sağlığı Anabilim Dalı, İzmir, Türkiye

${ }^{2}$ Aydın Adnan Menderes Üniversitesi, Hemşirelik Fakültesi, Halk Sağlığı Hemşireliği Anabilim Dalı, Aydın, Türkiye

${ }^{3}$ Aydın İl Sağlık Müdürlüğü Efeler Çeştepe Aile Sağlığı Merkezi, Aydın, Türkiye

ÖZ

\begin{abstract}
Amaç: Bu çalışma kadınların serviks kanserinin tanısına ilişkin tutumlarını ve ilişkili faktörleri belirlemek amacıyla yapılmıştır. Yöntem: Kesitsel tipteki bu araştırmanın evrenini Aydın İli Çeştepe Aile Sağlığı Merkezine kayıtlı 18 yaş üzeri 2049 kadın, örneklemini ise okuryazar, 18 yaş ve üstü 314 kadın oluşturmuştur. Veriler, kişisel bilgi formu ve Servikal Kanserin Erken Tanısına Yönelik Tutum Ölçeği ile toplanmıştır. Araştırma verileri, temel istatistiksel testlerin yanı sıra Student T ve lineer regresyon testi ile değerlendirilmiştir.

Bulgular: Kadınların \%26.8'sı düzenli jinekolojik muayene olduğunu, \%46.5'i pap smear yaptırdığı, \%3.5'i ailede serviks

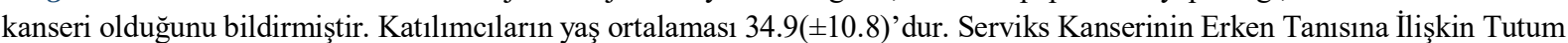
Ölçek toplam puanı 72.24'tir ( \pm 8.36 ). Ölçeğin Algılanan Duyarlılık Boyut puan ortalaması, çekirdek tipi ailede yaşayanlarda geniş ailede yaşayanlara göre 1.62 (\%95 GA:0.27-2.97) puan, ailede serviks kanseri olmayanlarda olanlara göre 2.47 (\%95 GA:0.27-4.67) puan, düzenli jinekolojik muayene olmayanlarda olanlara göre 2.17 (\%95 GA: 1.21-3.13) puan fazla bulunmuştur. Pap smear deneyimi yaşamamış olanlarda yaşamış olanlara göre Algılanan Engel Boyut puanı 0.58 (\%95 GA: 0.00-1.16) puan fazla, Algılanan Yarar Boyut puanı ise 0.69 (\%95 GA:0.07-1.30) puan fazla bulunmuştur.

Sonuç: Kadınların serviks kanserinin erken tanısına ilişkin tutum puanları ortalama düzeydedir. Kadınlara serviks kanseri tanı yöntemleri, risk faktörleri hakkında sağlık eğitimlerinin verilmesi, sağlıklı yaşam biçimi davranışlarının geliştirilmesi için desteklenmesi ve serviks kanseri hakkında farkındalığın artması sağlanabilir.
\end{abstract}

Anahtar Kelimeler: Erken tanı, Kadınlar, Serviks kanseri, Tutum, Jinekolojik muayene.

ABSTRACT

Objective: This study was conducted to determine women's attitudes and related factors to the diagnosis of cervical cancer. Methods: The population of this cross-sectional study consisted of 2049 women over the age of 18, enrolled in the Aydin Province Çeştepe Family Health Center. The sample consisted of 314 women aged 18 and over. The data were collected by Personal Information Form and Attitude Scale for Early Diagnosis of Cervical Cancer. Besides basic statistical tests, it was evaluated with student $\mathrm{T}$ and linear regression test.

Results: $26.8 \%$ of women reported regular gynecological examination, $46.5 \%$ had papsmear, $3.5 \%$ reported having servix cancer in the family. The average age of the participants is $34.9( \pm 10.8)$. The total score of the Attitude Scale Toward for Early Diagnosis of Cervical Cancer is 72.24 ( \pm 8.36$)$. The Perceived Sensitivity Dimension score of the scale is 1.62 (95\% CI: 0.272.97) points in the nuclear family compared to those living in the extended family, 2.47 (95\% CI: 0.27-4.67) score compared to those in the family without cervical cancer, 2.17 (95\% CI: 1.21-3.13) points were higher in those without regular gynecological examination. The Perceived Obstacle Dimension score was 0.58 (95\% CI: 0.00-1.16) points higher than those

Sorumlu Yazar: Safiye ÖZVURMAZ

Aydın Adnan Menderes Üniversitesi, Hemşirelik Fakültesi, Halk Sağlığı Hemşireliği Anabilim Dalı, Aydın, Türkiye

sozvurmaz@hotmail.com

Geliş Tarihi: 27.04.2020 - Kabul Tarihi: 21.09.2020

Yazar Katkıları: A) Fikir/Kavram, B) Tasarım, C) Veri Toplama ve/veya İşleme, D) Analiz ve/veya Yorum, E) Literatür

Taraması, F) Makale Yazımı, G) Eleştirel İnceleme 
who did not have Papsmear experience, the size of the Perceived Benefits score of 0.69 (95\% CI: 0:07 to 1:30) were more points.

Conclusion: The attitude scores of women regarding the early diagnosis of cervical cancer are average. It can be provided to women to provide health education about cervical cancer diagnosis methods and risk factors, to support healthy lifestyle behavior development to increase awareness about cervical cancer.

Key words: Early diagnosis, Women, Cervical cancer, Attitude, Gynecological examination.

\section{GíRiş}

Kanser, günümüzde toplumlarda ve her sosyo-ekonomik düzeyde görülen önemli bir hastalık olup, dünyadaki ikinci sıradaki ölüm nedenidir ve 2018'deki ölümlerin 9.6 milyonundan sorumludur. Tüm dünyada altı ölümden yaklaşık biri kanserden kaynaklanmaktadır (1).

Serviks kanseri kadınların yaşamında en önemli sağlık sorunlarından biridir (2). Serviks kanseri genel kanser ölümleri açısından üçüncü sıradadır. Çoğunlukla orta ve ileri yaş kadınlarda görülmesine rağmen herhangi bir yaşta da ortaya çıkabilmektedir (3). En yaygın kanser türlerinden olan serviks kanseri iyileşme potansiyeli olan, erken saptanabilen, önlenebilir kanserler arasındadır. Erken dönemde teşhis edilip tedavi edildiğinde iyileşme oranı yüksektir; ayrıca tam iyileşme sağlanabilmektedir $(3,4)$. Bu nedenle serviks kanserine bağlı ölümlerin azaltılması tarama yöntemlerinin uygulanıp takiplerine bağlıdır (3).

Serviks kanserinden korunma mümkündür. Ancak hem dünyada hem de ülkemizde farkındalık çalışmalarına ve daha yaygın tarama programlarına ihtiyaç vardır. Serviks kanserinin görülme sıklığını belirlemek, toplumsal duyarlılı̆̆1 artırmak, serviks kanseri ile ilişkili riskleri saptamak, korunma ve tedavide uygun stratejiler geliştirmek günden güne daha önemli hale gelmektedir (5). Yapılan çalışmalar bildirmektedir ki; çok eşlilik, cinsel aktivitenin erken başlangıcı, genital hijyenin kötü olması, oral kontraseptif kullanma, beslenme yetersizliği, bağışıklık sisteminin zayıf olması, sigara kullanımı, anormal pap smear test sonucu, erkeğin çok eşli olması, pap smear yaptırma oranında azlık ve ekonomik durum yetersizliği en önemli risk faktörleri arasındadır $(3,4,6)$. Human Papilloma Virüsü (HPV) gibi kansere neden olan enfeksiyonlar, düşük ve orta gelirli ülkelerde kanser vakalarının \%25'inden sorumludur (1). Hastalık bulguları genellikle menstrüasyon dönemlerindeki düzensizlikler, menopoz sonrasında devam eden lekelenme veya kanamalar, cinsel ilişki sırasında ya da sonrasında kanama ve ağrı, yorgunluk, kilo kaybı, iştahsızlık şeklinde kendini gösterir (3).

Serviks kanserine yönelik tarama programları, serviks kanserinin azalmasındaki önemli etkisine rağmen hala kadınlar serviks kanseri nedeniyle ölmektedir (7). Bu nedenle serviks kanserinin tanısına ilişkin tutumlarını, bu tutumları etkileyen faktörleri bilmek önemlidir. Bu çalışma, kadınların serviks kanserinin tanısına ilişkin tutumlarını ve ilişkili faktörleri belirlemek amaciyla planlanmıştır.

\section{GEREÇ VE YÖNTEM}

Araştırma kesitsel tipte bir çalışmadır. Aydın ili Efeler Merkez, Çeştepe Aile Sağlığ Merkezi'nde (ASM), 15 Ağustos 2018- 15 Şubat 2019 tarihleri arasında yapılmıştır. 


\section{Araştırmanın Evreni ve Örneklemi}

Araştırmanın evrenini Aydın İli Çeştepe Aile Sağlığı Merkezine (ASM) kayıtlı 18 yaş üzeri 2049 kadın oluşturmuştur. Örneklem, G-power programı ile 0.80 güç 0.05 güven aralığ1, df:10, 0.25 (orta) etki boyu ile hesaplanmış ve 269 kadına ulaşılması hedeflenmiştir. ASM koşullarında çalışmaya davet edilen 314 gönüllü kadına çalışma saatleri içerisinde anket uygulanmıştır. Çalışmaya 18 ve üstü yaş olan, çalışmaya katılmayı kabul eden, okuryazar olan (öz bildirim ölçeği kullanılması nedeni ile) kadınlar alınmıştır.

\section{Veri Toplama Form ve Araçları}

\section{Araştırmanın Verileri}

Araştırmanın verileri Kişisel Bilgi Formu ve Servikal Kanserin Erken Tanısına Yönelik Tutum Ölçeği (SKETTÖ) ile toplanmıştır.

\section{Kişisel Bilgi Formu:}

Kadınların sosyo-demografik özellikleri, düzenli jinekolojik muayene yaptırma ve ailede servikal kanser tanısı alma durumunu değerlendiren 6 soruluk veri toplama formudur. Araştırmacılar tarafından literatür doğrultusunda $(8,9)$ ve uzman görüşü (İki halk sağllğ 1 uzmanı, iki uzman hemşire, iki birinci basamak hekim) alınarak oluşturulan formlar, katılımcılara gözlem altında uygulanmıştır.

\section{Servikal Kanserin Erken Tanısına Yönelik Tutum Ölçeği (SKETTÖ):}

Özmen ve Özsoy (2009) tarafından geliştirilen ölçeğin, Sağlık İnanç Modeli’nin dört alt boyutunu araştırmak amacıyla yapılandırılmış olup dört alt boyutu vardır (10). Algılanan duyarlılık alt boyutu dokuz maddeden, algilanan ciddiyet alt boyutu sekiz maddeden, algılanan engel alt boyutu yedi maddeden, algılanan yarar alt boyutu ise altı maddeden oluşmaktadır. Ölçek ve alt boyutları için Cronbach alfa katsayısı 0.89-0.70 arasındadır. Ölçekten alınan puanın yüksek olması bireylerin serviks kanseri erken tanısına ilişkin olumlu tutumlarının yüksek olduğunu göstermektedir. Bu çalışmada tüm ölçek için verilerin bu Kaiser-Meyer-Olkin Örneklem Ölçüm Değer Yeterliliği 0.678 iken boyutlar için sırayla 0.580 ve $0.598,0.593,0.484$ bulunmuştur. Cronbach alfa değerleri ölçek için 0.633 (min:0.571. Max:0.629) bulunmuştur.

\section{Verilerin Toplanması ve Değerlendirilmesi}

Veriler kadınların ASM ortamında, yaklaşık 10-15 dakikada toplanmıştır. Elde edilen veriler SPSS istatistik paket programında (Version 23, Chicago IL, USA) değerlendirilmiştir. Normal dağılımın belirlenmesinde Gauss Eğrisi, Minimum ve Maksimum Değerler, Kolmogorov Simirnov testi kullanılmıștır. Normal dağılım gösteren değişkenler temel istatistiksel testlerin yanı sıra student $\mathrm{T}$ ve lineer regresyon testi ile değerlendirilmiştir. Normal dağılımın sağlanamaması durumunda Mann Whitney U, Kruskal Wallis testi kullanılmıştır.

\section{Etik Açıklamalar}

Aydın Adnan Menderes Üniversitesi Hemşirelik Fakültesi Girişimsel Olmayan Klinik Araştırmalar Etik Kurulu'ndan Etik Kurul izni alınmıştır (Sayı: 50107718-050.99). Araştırmaya katılan bireylerden yazılı onam ve kurum izinleri alınmıştır. 


\section{BULGULAR}

Çalışmada 314 bireye ulaşılmıştır. Kadınların \%26.8'i düzenli jinekolojik muayene olduğunu, \%46.5'i pap smear yaptırdığını, \%3.5'i ailede serviks kanseri olduğunu belirtmiştir (Tablo 1). Katılımcıların yaş ortalaması $34.9 \pm 10.8$ ve medyanı 33 (18-68)'tür ve kadınların \%64.6's1 40 yaş altındadır. Kadınların \%80.3'ü evli, \%89.2'si çekirdek aile üyesi ve \% 7.0 'sinin geliri giderinden fazladir.

Tablo 1. Katılımcıların Özellikleri

\begin{tabular}{llll}
\hline Özellikler & & $\mathrm{N}$ & $\%$ \\
\hline \multirow{2}{*}{ Yaş grubu } & $0-39$ & 203 & 64,6 \\
& 40 ve üzeri & 111 & 35,4 \\
Medeni durum & Toplam & 314 & 100 \\
& Bekâr & 54 & 17,2 \\
& Boşanmış, dul & 8 & 2,6 \\
& Evli & 252 & 80,3 \\
Aile Tipi & Toplam & 314 & 100 \\
& Çekirdek aile & 280 & 89,2 \\
& Geniş Aile & 31 & 9,9 \\
& Yalnız & 3 & 1,0 \\
Gelir-Gider durumu & Toplam & & \\
& Gelir giderden az & 117 & 37,3 \\
& Gelir gidere denk & 175 & 55,7 \\
Düzenli jinekolojik muayene & Gelir giderden fazla & 22 & 7,0 \\
& Toplam & 314 & 100 \\
& Hayır & 230 & 73,2 \\
Şimdiye kadar pap smear yaptırma & Evet & 84 & 26,8 \\
& Toplam & 314 & 100 \\
& Hayır & 168 & 53,5 \\
& Evet & 146 & 46,5 \\
& Toplam & 314 & 100 \\
& Hayır & 303 & 96,5 \\
& Evet & 11 & 3,5 \\
& Toplam & 314 & 100 \\
\hline
\end{tabular}

Serviks Kanserinin Erken Tanısına İlişkin tutum ölçek total ortalama puanı $72.24 \pm 8.36$ 'tir. Ölçeğin alt boyutlarından olan "algılanan duyarlılık" ortalaması $24.04 \pm 3.81$; "algılanan ciddiyet" ortalaması $20.26 \pm 4.11$; "alg1lanan engel" ortalamas1 $14.46 \pm 2.61$; "algılanan yarar" ortalaması $13.49 \pm 2.60$ bulunmuştur (Tablo 2).

Çoklu değişkenler ile yapılmış analizler göstermiştir ki, ölçeğin algılanan duyarlılık boyut puanı, çekirdek tipi ailede yaşayanlarda geniş ailede yaşayanlara göre 1.62 (\%95 GA:0.27-2.97) puan, ailede serviks kanseri olmayanlarda olanlara göre 2.47 (\%95 GA:0.274.67) puan, düzenli jinekolojik muayene olmayanlarda olanlara göre 2.17 (\%95 GA: 1.21-3.13) puan fazla bulunmuştur. Ancak tekli değişken analizlerinde bulunan yaş ve medeni durum ile algılanan duyarlılık alt boyut ilişkisi anlamını yitirmiştir. Ölçeğin algılanan ciddiyet puanı, çekirdek tipi ailede yaşayanlarda geniş ailede yaşayanlara göre 1.93 (\%95 GA: 0.43-3.44) puan 
fazla saptanmıştır. Pap smear yaptırmamış olanlarda yaşamış olanlara göre algılanan engel boyut puanı 0.58 (\%95 GA: 0.00-1.16) puan fazla, algılanan yarar boyut puanı ise 0.69 (\%95 GA:0.07-1.30) puan fazla bulunmuştur. Tekli değişken analizleri ile saptanmış olan yaş ilişkisi ise anlamını yitirmiştir (Tablo 3).

Tablo 2. Servikal Kanserin Erken Tanısına Yönelik Tutum Ölçeği ve Alt Ölçek Puanları (N=314)

\begin{tabular}{lccc} 
& Ortalama & Median & Minimum- Maksimum \\
\hline Ölçek Total* & $85,28 \pm 9,86$ & 86 & $48-117$ \\
\hline Algılanan duyarlılık (Boyut 1) & $24,04 \pm 3,81$ & 24 & $13-36$ \\
Algılanan ciddiyet (Boyut 2) & $20,26 \pm 4,11$ & 20 & $8-31$ \\
Algılanan engel (Boyut 3)* & $14,46 \pm 2,61$ & 14 & $7-22$ \\
Algılanan yarar (Boyut 4) & $13,49 \pm 2,60$ & 14 & $6-23$ \\
\hline
\end{tabular}

*311 katılımcının değerleridir.

Tablo 3. Hemşirelerin Hasta Teslimi İle İlgili Düşünceleri

\begin{tabular}{|c|c|c|c|c|c|c|c|}
\hline \multicolumn{2}{|l|}{ Özellikler } & \multirow[t]{2}{*}{$\mathrm{n}$} & \multirow[t]{2}{*}{ Ortalama } & \multirow[t]{2}{*}{$\mathrm{p}$} & \multirow[t]{2}{*}{ B } & \multicolumn{2}{|c|}{$\begin{array}{l}\% 95 \text { Güven } \\
\text { Aralığ1 }\end{array}$} \\
\hline \multicolumn{4}{|c|}{ BOYUT 1: Algılanan duyarlılık } & & & & \\
\hline \multirow[t]{2}{*}{ Yaş } & $\geq 40$ & 111 & $23,45 \pm 4,18$ & \multirow{2}{*}{0,044} & \multirow[t]{2}{*}{0,30} & \multirow[t]{2}{*}{$-0,59$} & \multirow[t]{2}{*}{1,19} \\
\hline & $<40$ & 203 & $24,35 \pm 3,55$ & & & & \\
\hline \multirow[t]{2}{*}{ Medeni durum } & Evli & 252 & $23,78 \pm 3,79$ & \multirow{2}{*}{0,017} & \multirow[t]{2}{*}{0,64} & \multirow[t]{2}{*}{$-0,45$} & \multirow[t]{2}{*}{1,72} \\
\hline & Evli değil & 62 & $25,06 \pm 3,71$ & & & & \\
\hline \multirow[t]{2}{*}{ Aile tipi } & Çekirdek aile & 280 & $24,19 \pm 3,77$ & \multirow{2}{*}{0,029} & $1,62^{*}$ & \multirow[t]{2}{*}{0,27} & \multirow[t]{2}{*}{2,97} \\
\hline & Geniş Aile & 31 & $22,61 \pm 4,02$ & & Ref & & \\
\hline \multirow[t]{2}{*}{ Ailede serviks kanseri } & Hayır & 303 & $24,14 \pm 3,72$ & \multirow{2}{*}{0,011} & $2,47^{*}$ & \multirow[t]{2}{*}{0,27} & \multirow[t]{2}{*}{4,67} \\
\hline & Evet & 11 & $21,18 \pm 5,12$ & & Ref & & \\
\hline \multirow[t]{2}{*}{ Düzenli jinekolojik muayene } & Hayır & 230 & $24,67 \pm 3,52$ & \multirow{2}{*}{0,000} & $2,17^{*}$ & \multirow[t]{2}{*}{1,21} & \multirow[t]{2}{*}{3,13} \\
\hline & Evet & 84 & $22,31 \pm 4,04$ & & Ref & & \\
\hline \multicolumn{8}{|l|}{ BOYUT 2: Algılanan ciddiyet } \\
\hline \multirow[t]{2}{*}{ Aile tipi } & Çekirdek aile & 280 & $20,45 \pm 4,08$ & \multirow{2}{*}{0,012} & $1,93 *$ & 0,43 & 3,44 \\
\hline & Geniş Aile & 31 & $18,52 \pm 3,67$ & & Ref & & \\
\hline \multirow[t]{2}{*}{ Pap Smear deneyimi } & Yok & 166 & $14,73 \pm 2,77$ & \multirow{2}{*}{0,049} & $0,58^{*}$ & 0,00 & 1,16 \\
\hline & Var & 145 & $14,15 \pm 2,38$ & & Ref & & \\
\hline \multirow[t]{2}{*}{ Yaş } & $<40$ & 203 & $13,76 \pm 2,42$ & 0015 & 0,49 & $-0,15$ & 1,13 \\
\hline & $\geq 40$ & 111 & $13,01 \pm 2,86$ & 0,015 & Ref & & \\
\hline Pap Smear deneyimi & Yok & 168 & $13,89 \pm 2,63$ & 0003 & $0,69 *$ & 0,07 & 1,30 \\
\hline & Var & 146 & $13,03 \pm 2,50$ & 0,003 & Ref & & \\
\hline
\end{tabular}

\section{TARTIŞMA}

Serviks kanseri, önemli bir halk sağlığı sorunu olup, pap smear testi ucuz ve kolay uygulanabilir en etkin tarama yöntemidir. Amerikan Kanser Birliği'nin önerisine göre pap smear testi ilk cinsel ilişkiden itibaren üç yıl içerisinde ve her yıl yaptırılmalıdır (11). Dünya Sağlık Örgütü, 2015 yılı verilerinde 8.8 milyon kişinin ölüm nedeninin kanser olduğunu; her altı ölümden birinin kanser ve kansere bağlı komplikasyonlardan dolayı gerçekleştiğini bildirmektedir (12). Bu çalışma, kırsal bölgede yaşayan kadınların serviks kanserinin tanısına 
Adnan Menderes Üniversitesi Sağlık Bilimleri Fakültesi Dergisi 2021: 5(1); 26-36

Journal of Adnan Menderes University Health Sciences Faculty

ilişkin tutumlarını ve ilişkili faktörleri belirlemek amacıyla kırsal bir bölgede yaşayan 314 kadın ile kesitsel olarak yapılmıştır. Kadınların \%26.8'i düzenli jinekolojik muayene, \%46.5'i pap smear testi yaptırdığını, \%3.5'inde ailede serviks kanseri olduğunu bildirmiştir. Serviks kanserinin, yaygın olarak 35 ile 50 yaş arasındaki genç kadınları etkilediği ve tanı konduğunda yaş ortalamasının 48.7 olduğu belirtilmektedir (13). T.C. Sağlık Bakanlığı Türkiye Halk Sağlığ Kurumu'nun yapmış olduğu çalışmaya göre serviks kanserine yakalananların çoğunluğu ileri evrede teşhis edilmektedir (14). Bu çalışmada kadınların yaş ortalaması 34.9'dur ve \%64.6'sı 40 yaş altındadır. Serviks kanserine ilişkin yapılmış çalışmalarda yaş ortalamaları $43.36 \pm 7.47$

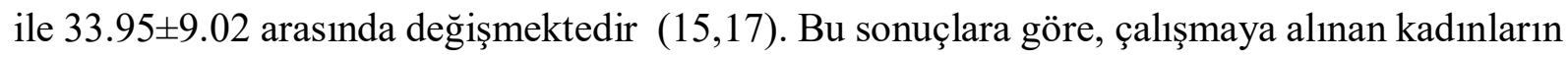
yaş ortalaması serviks kanseri için riskli yaş grubunda olup; serviks kanseri açısından bilgi, tutum ve davranışları erken tanı ve tedavi açısından önemlidir. Sağlık çalışanlarının serviks kanseri riskini artıran faktörler konusunda kadınların bilinçlendirilmesi ve önlemlerin alınması, sağlığın korunması sürecinde bu yaş grubundaki kadınlara sağlığ 1 koruyucu ve geliştirici uygulamaların öğretilmesi ve desteklenmesi oldukça önemlidir.

Çalışmamızda kadınların \%80.3'ü evli, \%89.2'si çekirdek aile üyesi ve \%7.0'sinin geliri giderinden fazladır. Çalışmamızda ölçeğin algılanan ciddiyet puanı, çekirdek tipi ailede yaşayanlarda 1.93 puan fazla saptanmıştır. Ancak medeni durum ve gelir durumuna ilişkin farklılık saptanmamıştır. Serviks kanserine ilişkin yapılmış çalışmalarda bireylerin \% $\% 4.0$ ile \%97.4 arasında evli olduğu saptanmıştır $(17,18)$. Kırsal bölgede yaşamak, sosyodemografik özellikleri etkileyen önemli faktörlerden biridir. Yapılan araştırmalar, pap smear testi yaptırma oranlarında farklılıklar göstermektedir. Ranabhat ve arkadaşları (2014) tarafından yürütülen kadınların servikal pap smear uygulamalarına yönelik çalışmada kadınların \%32.5'inin kentlerde yaşadı ̆̆ 1 ve kentlerde yaşayanların \%22.8'inin, kırsalda yaşayanların \%13.7' sinin pap smear testini yaptırdıkları, yoksul kadınların daha düşük düzeyde pap smear testi yaptırdıkları bildirilmiştir (16) (19,21). Yapılan araştırmalar, gelir durumunun erken tanı ve tedavi amacıyla kullanılan pap smear testini yaptırma ve serviks kanseri hakkındaki bilgi düzeyini etkilediği ve aralarında pozitif yönlü bir ilişkinin olduğunu göstermektedir (24-26). Breitkopf ve arkadaşları (2005) çalışmalarında da gelir düzeyi düşük kadınların pap smear yaptırma oranları \%16.7, yüksek kadınların \%50 olduğunu belirtmiştir (22). Ayrıca sosyal güvencesi olan kadınlarda pap smear testini yaptırma oranının daha yüksek olduğunu gösteren çalışma da mevcuttur (23). Sağlık çalışanlarının, kadınlara düzenli olarak taramalar ve jinekolojik muayeneleri hakkında sağlık eğitimi planlanması ve uygulanması, konuyla ilgili bilgi düzeyleri ve farkındalık geliştirmeleri konusunda etkili olabilir.

Çalışmamızda kadınların yaşı ile serviks kanserine yönelik tutumları arasında bir fark bulunmamıştır. Kalyoncu ve arkadaşlarının (2003) çalışmasında kadınların yaşları ve eğitim düzeyleri arttıkça ve sosyal güvenceleri varsa pap smear yaptırma oranlarının artmış olduğu, kadınların \%75'inin pap smear testini duydukları ve pap smear testini duyduğunu belirten kadınların \%96'sının daha önce pap smear testi yaptırdığı belirtilmiştir (20). Gümüş ve Çam (2011), çalışmalarına katılan kadınlarının yaklaşık yarısının pap smear testini bildiğini ancak düzenli olarak yaptırmadıklarını bildirmişlerdir (2).

Bu çalışmada Serviks Kanserinin Erken Tanısına İlişskin tutum ölçek toplam ortalama puanı $72.24 \pm 8.36$ 'dır. Ölçeğin alt boyutlarından olan "algılanan duyarlılık" puan ortalaması orta düzeyde (24.04 \pm 3.81$)$, "alg1lanan ciddiyet" puan ortalamas1 (20.26 \pm 4.11$)$, "alg1lanan engel” puan ortalaması (14.46 \pm 2.61$)$, "algılanan yarar” ortalaması (13.49 \pm 2.60$)$ düşük düzeyde 
bulunmuştur. Sağlıklı davranışları benimsemedeki güçlü algılardan biri "algılanan duyarlılık" tır. Algılanan duyarlılığın artması ile riski azaltıcı davranışı gösterme olasılığı da artmaktadır (27). Duyarlılık alt boyutu algısının artması ile sağlık davranışının olumlu yönde etkilendiği ve bireyin aldığı sağlık eğitimin duyarlılık algısını artırdığı söylenebilir.

Sağlık inanç modeline göre, pap smear testinin yararlılı̆̆ına dair olumluluk algısı artıkça, duyarlılık ve ciddiyet algıları da artmakta olup, algılanan duyarlılığın artması ile risk azaltıcı davranış gösterme olasılığ 1 da artmaktadır $(6,28,29)$.

Çoklu değişkenler ile yapılmış analizler göstermiştir ki; ölçeğin algılanan duyarlılık alt boyut puanı, çekirdek ailede yaşayanlarda geniş ailede yaşayanlara göre, ailede serviks kanseri olmayanlarda olanlara göre, düzenli jinekolojik muayene olmayanlarda olanlara göre fazla bulunmuştur.

Ciddiyet algısı kişinin, hastalığa yakalanmanın yaratacağı durum, hastalığın tedavisi olmaması, ölüme, sakatlığa, ağrıya yol açması gibi tıbbi/klinik sonuçları hakkındaki değerlendirmesini, ayrıca hastalığın sosyal yaşam üzerine olası etkileri hakkında hissettiği duyguları ifade etmektedir. Bu bağlamda serviks kanseri özelinde düşünüldüğünde; bir kadının hastalığı ciddi olarak algılaması hastalığa yakalanması halinde ciddi tıbbi, sosyal ve ekonomik kayıpların olacağını bildiğini ve pap smear testi yaptırma olasılığının daha yüksek olduğunu göstermektedir (32). Bu çalışmada ciddiyet algısı düşük düzeyde bulunmuştur; dolayısıyla kadınların serviks kanseri ile ilgili farkındalıklarının geliştirilmesi ve ilgili konuyla ilgili olumlu davranış değişikliğinin sağlanması gereklidir. "Algılanan engel” davranış değişikliğinde sağlıkla ilgili harekete geçmenin negatif yönüdür. Bir başka deyişle algılanan engel sağlığa ilişkin koruyucu davranışı engelleyen ya da zorlaştıran etmenlerle ilgili algıdır (27,31). Bu çalışmada, Pap smear deneyimi yaşamamış olanlarda yaşamış olanlara göre algılanan engel boyut puanı 0.58 (\%95 GA: 0.00-1.16) puan fazla bulunmuştur. Algılanan engelin bireylerin serviks kanserine yönelik koruyucu davranışlarını olumsuz etkilediği görülmektedir. Algılanan duyarlılık, ciddiyet ve yarar, ancak algılanan engellerin etkisini azaltırsa, davranış gerçekleştirilir. Pap smear testini yaptırmayla ilgili algılanan engeller arasında; algılanan sağlık düzeyinin düşüklüğü, yetersiz motivasyon, hizmetlerin ulaşımındaki yetersizlikler, sağlık çalışanına karşı olumsuz tutum, sağlık çalışanının cinsiyeti, pap smear testi yaptırmaktan korkma, kanser ve erken tanı ile ilgili bilgi eksikliği sayılabilir (33,34). McFarland (2003), çalışmasında kadınların pap smear yaptırmaya yönelik olarak engelleri bireysel ve sisteme yönelik engeller olarak tanımlamıştır $(35,36)$.

“Algılanan Yarar"da birey koruyucu bir sağlık davranışı göstermesinin kendisine yararı olacağını düşünmektedir. Bu yarar, hastalığa yakalanma olasılığının azalacağına ilişkin beklentidir (27). Latin Amerika'da yapılan bir çalışmada yoksul kadınların pap smear yaptırmaya yönelik algılanan yararları arasında pap smear testi sonucunun negatif çıkmasının kendilerini rahatlatacağ 1 duygusu olarak belirlenmiştir (37). Pap smear deneyimi yaşamamış olanlarda yaşamış olanlara göre algılanan yarar boyut puanı fazla bulunmuştur. Jirojwong ve arkadaşları (2001), algılanan yarar düzeyi yüksek kadınların pap smear yaptırma oranlarının 1.3 kat fazla olduğunu belirtmişlerdir (30). Yayınlanmış çalışmalarda, düşük engel algısının taramalara katılımı azaltmada ve yüksek yarar algısının taramalara katılımı artırmada etkili olduğu görülmektedir $(38,39)$. Bir davranışın gerçekleşmesinde, bireylerin bu davranışla ilgili yarar göreceği beklentisi önemlidir. Çalışmamızda pap smear testi yaptıran kadınların 
algılanan yarar alt boyutu puanlarının yüksek olmasının nedeni olarak bu testin kendilerini koruyacağına ilişkin inançları olarak düşünülmüştür.

\section{SONUÇ VE ÖNERILLER}

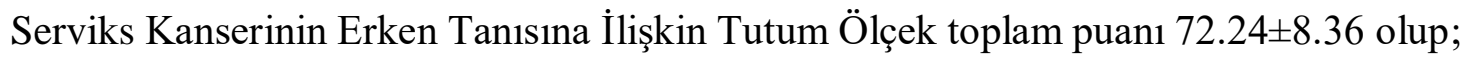
ölçeğin algılanan duyarlılık boyut puanı, çekirdek tipi ailede yaşayanlarda, ailede serviks kanseri olmayanlarda, düzenli jinekolojik muayene olmayanlarda, algılanan engel boyut puanı ve algılanan yarar boyut puanı pap smear deneyimi yaşamamış olanlarda fazla bulunmuştur.

Kadınlara serviks kanseri tanı yöntemleri, risk faktörleri hakkında sağlık eğitimlerinin verilmesi, sağlıklarını korumaya ve geliştirmeye yönelik sağlıklı yaşam biçimi davranışlarının geliştirilmesi için desteklenmesi ve serviks kanseri hakkında farkındalığın artması sağlanabilir. Serviks kanseri tarama programlarının ve sunulan sağlık hizmetinin etkili olabilmesi, katılımın arttırılması için uygun bir şekilde sunulması sağlanabilir; kampanyalarla birlikte, grup eğitimleri, eğitim kitapçıkları dağıtılabilir.

\section{Çalışmanın Sınırlılıkları}

Bu çalışmanın evreni Aydın İlinde bir sağlık ocağı bölgesinde yaşayan kadın sayısı ile sınırlıdır. Çalışmada elde edilen veriler kullanılan ölçüm araçları ile sınırlıdır.

\section{Araştırmanın Etik Yönü}

Aydın Adnan Menderes Üniversitesi Hemşirelik Fakültesi Girişimsel Olmayan Klinik Araştırmalar Etik Kurulu'ndan Etik Kurul izni alınmıştır (Sayı: 50107718-050.99). Araştırmaya katılan bireylerden yazılı onam ve kurum izinleri alınmıştır.

\section{Çıkar Çatışması}

Yazarlar arasında çıkar çatışması yoktur.

\section{KAYNAKLAR}

1. World Health Organization. Cancer. (2018). https://www.who.int/news-room/factsheets/detail/cancer (Erişim Tarihi: 8 Ağustos 2019).

2. Gümüş, A. B., Çam, O. (2011). Serviks kanseri için erken tanı tutumları ile benlik saygısı, beden algısı ve umutsuzluk düzeyleri arasındaki ilişkiler. Nobel Medicus, 7(3), 46-52

3. Halk Sağlı̆̆1 Genel Müdürlüğü.(2018), Rahim Ăğzı (Serviks) Kanseri https://hsgm.saglik.gov.tr/depo/birimler/kanserdb/il_Faaliyetleri/Kilis/Kilis_serviks_c a 2018/basin notu.pdf._(Erişim Tarihi: 10 Ağustos 2019).

4. T.C. Sağlık Bakanlığı Halk Sağlığı Genel Müdürlüğü. (2017), 08 Mart 2019. Erişim Adresi: https://hsgm.saglik.gov.tr/tr/kanser-turleri/kanser-turleri/362-kanser-dairesibaskanligi-kanser-turleri-serviks-kanseri.html_(Erişim Tarihi: 5 Ağustos 2019).

5. Kanbur, A., Çapık, C. (2011). Servikal kanserden korunma, erken tanı-tarama yöntemleri ve ebe/hemşirenin rolü. Hacettepe Üniversitesi Să̆llk Bilimleri Fakültesi Hemşirelik Dergisi, 18(1), 61-72 
6. Bal, M. D.(2014). Kadınların pap smear testi yaptırma durumlarının sağlık inanç modeli ölçeği ile değerlendirilmesi. Marmara Üniversitesi Sağllk Bilimleri Enstitüsü Dergisi 4(3), 133-138.

7. Sivri, A., Ekmez, D., Göksedef, M., Hasanova, B. P., Aş1k, M., Çetin, A. (2015). Polikliniğe başvuran kadınlarda smear farkındalığı ve yaptırma sıklığı. Türk Jinekolojik Onkoloji Dergisi. 4, 127-130

8. Ifediora,C.O. (2019). Re-thinking breast and cervical cancer preventive campaigns in developing countries: the case for interventions at high schools.BMC Public Healty, 19,503

9. Uluocak,T., \& Bekar,M. (2012). Kadın sağlık çalışanlarının servikal kansere ilişkin bilgi ve tutumlarının belirlenmesi.Türk Jinekolojik Onkoloji Dergisi. 2, 50-57.

10. Özmen, D., \& Özsoy, S. (2009). Sağlık inanç modeli yaklaşımı ile servikal kanserin erken tanısına yönelik tutum ölçeği geliştirilmesi. Ege Üniversitesi Hemşirelik Yüksek Okulu Dergisi. 25(1), 51-69.

11. American Cancer Society. (2010). Cervical cancer:prevention and early detection. http://www.cancer.org/Cancer/CervicalCancer/MoreInformation/CervicalCancerPrev entionandEarlyDetection/cervicalcancer-prevention-and-early-detection-find-precancerchanges. (Erişim Tarihi: 18 Eylül 2019).

12. World Health Organization.,. Cancer. (2018). https://www.who.int/cancer/en/ (Erişim Tarihi: 25 Eylül 2019).

13. Arbyn, M., Anttila, A., Jordan, J., Ronco, G., Schenck, U., Segnan, N., et al. (2010) European guidelines for quality assurance in cervical cancer screening. second editionsummary document. Annals of Oncology. 21(3), 448-58.

14. T. C. Sağlık Bakanlığı Türkiye Halk Sağlı̆̆1 Kurumu. Türkiye Kanser Istatistikleri 2016. https://hsgm.saglik.gov.tr/depo/birimler/kanserdb/istatistik/Trkiye_Kanser_statistikleri_2016.pdf(Erişim Tarihi: 8 Ağustos 2019)

15. Öztürk, Y. (2017). Pap smear testi yaptırmamış kadınların bu teste yönelik farkındalıklarının ve testi yaptırmama nedenlerinin değerlendirilmesi. Sağlık Bilimleri Enstitüsü, Hemşirelik Anabilim Dalı, Yüksek Lisans Tezi, Osmangazi Üniversitesi. Eskişehir.

16. Ranabhat, S., Tiwari, M., Dhungana,, G., Shrestha, R.(2014). Association of knowledge, attitude and demographic variables with cervical pap smear practice in Nepal, Asian Pacific Journal of Cancer Prevention(Electronic Journal) ,15(20)8905$8910 . \quad$ http:// journal. waocp. org/article 30015 5e62f74df6bd45f1d0b555cf688bc813.pdf (Erişim Tarihi: 8 Ağustos 2019).

17. Reis, N., Bebis, H., Kose, S., Sis, A., Engin, R., Yavan, T. (2012).Türk kadınlarında rahim ağzı kanseri ve taramasına ilişkin bilgi, davranış ve inançlar (Knowledge, behavior and beliefs related to cervical cancer and screening among Turkish women).Asian Pacific Journal of Cancer Prevention,(Electronic Journal),13(4),14631470. http:// journal. waocp. org/article_ 26354_20574ee5f859afcc428c7257cf5aa5c7.pdf (Erişim Tarihi: 8 A ğustos 2019).

18. Örenli, G. (2015). İlk Öğretim ikinci kademede öğrenim gören kız öğrencilerin annelerinin rahim ağızı kanseri ve Hpv aşısı konusunda bilgi tutum davranışları. Sağlık Bilimleri Enstitüsü, Halk Sağlı̆̆ Anabilim Dalı, Yüksek Lisans Tezi. T.C. Bülent Ecevit Üniversitesi. Zonguldak.

19. Ideström, M., Milsom, I., Ellström, A. A. (2002). Knowledge and attitudes about the pap smear screening program: a population based study of women aged 20-59 years. Acta Obstetr Gynecol Scand, 81(10), 962- 967. 
20. Kalyoncu, C., Işıklı, B., Özalp, S., Küçük, N. (2003). Osmangazi Üniversitesi kadın hastalıkları ve doğum polikliniğine başvuranların pap smear hakkında bilgi, tutum ve davranışları. Să̆llk ve Toplum. 13, 60-66.

21. McFarland, D. M. (1999). Cervical cancer and pap smear screening in Botswana: knowledge and perceptions. Doctoral thesis, Boston College, Graduate School of Nursing. Massachusetts, United States. 50(3), 167-75

22. Breitkopf, R.C., Pearson, H. C., Breitkopf, D. M. (2005). Poor knowledge regarding the pap test among low-1ncome women undergoing routine screening. Perspectives on Sexual and Reproductive Health, 37(2), 78-84

23. Akyüz, A., Güvenç, G., Yavan, T., Çetintürk, A., Kök, G. (2006). Kadınların pap smear yaptırma durumları ile bunu etkileyen faktörlerin belirlenmesi. Gülhane Tıp Dergisi, 48, 25-29.

24. Datta, G.D., Graham A.C., Kawachi I., Subramanian S.V., Palmer J.R., Rosenberg L. (2006). Individual-, neighborhood-, and state-level socioeconomic predictors of cervical carcinoma screening among U.-S. black women: a multilevel analysis. American Cancer Society, 106(3), 664-69

25. Öztürk, Y. (2017). Pap smear testi yaptırmamış kadınların bu teste yönelik farkındalıklarının ve testi yaptırmama nedenlerinin değerlendirilmesi. Sağlık Bilimleri Enstitüsü, Hemşirelik Anabilim Dalı, Yüksek Lisans Tezi. T.C. Eskişehir Osmangazi Üniversitesi, Eskişehir.

26. Hanisch, R., Gustat, M. E., Hagensee, A., Baena, J. E., Salazar, M. V. Castro, A. M. et al. (2007). Knowledge of pap screening and human papillomavirus among women attending clinics in Medellín, Colombia. International Journal Of Gynecological Cancer, 12, 1020-1026

27. Glanz, K., Rimer, B. K., Viswanath, K. (Eds.). (2008). Health behavior and health education: Theory, research, and practice. San Francisco. (4th ed.). Jossey-Bass.

28. Ibekwe, C.M., Hoque ,M.E., Ntuli-Ngcobo, B. (2010). Perceived benefits of cervical cancer screening among women attending Mahalapye District Hospital, Botswana. Asian Pacific Journal of Cancer Prevention, 11(4), 1021-1027.

29. Winkler, J., Bingham, A., Coffey, P., Handwerker, W.P. (2008). Women's participation in a cervical cancer screening program in Northern Peru. Hlth Educa Res., 23(1), 10-24

30. Jirojwong, S., Maclennan, R., Manderson, L. (2001). Health beliefs and pap smears among Thai Women in Brisbane, Australia. Asia-Pacific Journal of Public Health., 13(1), 19-23

31. American Cancer Society (ACS) [Online]. The American Cancer Society guidelines for the prevention andearly detection of cervical cancer. http://www.cancer.org/cancer/cervical cancer/moreinformation/cervicalcancerpreventionandearlydetection/cervical-cancer prevention-and-early-detection-cervical-cancer-screening guidelines, (Erişim Tarihi: 8 Ağustos 2019).

32. Saslow, D., Runowicz, C.D., Solomon, D., Moscicki, A.B., Smith, R.A., Eyre H.J., et al. (2002). American cancer society guideline for the early detection of cervical neoplasia and cancer. CA Cancer J Clin., 52, 342-62.

33. Juon, H., Seung-Lee, C., Klassen, A.C. (2003). Predictors of regular pap smear among Korean-American women. Preventive Medicine, 37, 585-592.

34. Wong, L. P., Wong, Y. L., Low, W. Y., Khoo, E. M., Shuib, R. (2009). Knowledge and awareness of cervical cancer and screening among Malaysian women who have never had a pap smear: a qualitative study. Singapore Medical Journal, 50(1), 49-53 
35. McFarland, D. M. (2003). Cervical cancer and pap smear screening in Botswana: knowledge and perceptions. International Nursing Review, 50, 167-175.

36. Boyer, L.E., Williams, M., Callister, L.C., Marshall, E.S. (2001). Hispanic women ${ }^{\text {ee }}$ perceptions regarding cervical cancer screening. JOGNN., 30(2), 240-245.

37. Agurto, I., Bishop, A., Sanchez, G., Betancourt, Z., Robles, S. (2004). Perceived barriers and benefits to cervical cancer screening in Latin America. Preventive Medicine, 39(1), 91-98.

38. Menon, Uç, Szalacha, L.A., Prabhughate, A. (2012). Breast and cervical cancer screening among South Asian immigrants in the United States. Cancer Nursing, 35(4), 278-87.39.

39. Lee, E.E., Fogg, L., Menon, U. (2008). Knowledge and beliefs related to cervical cancer and screening among Korean American women. Western Journal of Nursing Researc,30(8), 960-974. 